\title{
Tax Reform and Investment: How Big an Impact?
}

\author{
Steven M. Fazzari
}

$\mathbf{T}$ legislation that revises the fundamental structure of U.S. income tax law. Promoters of this legislation hope that the new tax system will encourage more producfive use of economic resources and faster economic growth. Economists disagree very little about the general objectives of tax reform. The new law, however, has drawn significant criticism, primarily because of its treatment of capital investment. The new law weakens or eliminates many tax initiatives originally designed to stimulate investment.

This article analyzes the effect of tax reform on investment and the U.S. capital stock. It discusses the channels through which changes in the corporate income tax rate, the investment tax credit and the rules for deducting depreciation expense from taxable income affect the cost of capital and a firm's investment decisions. Furthermore, this article assesses how the increase in corporate taxes affects investment. First however, the next section presents some capital theory concepts that provide a framework for understanding tax effects on investment.

\section{SOME BASIC CONCEPTS IN CAPITAL THEORY}

A firm invests to maintain and expand its stock of productive capital. Most economic models of invest-

Steven Fazzari, an assistant professor of economics at Washington University in St. Louis, is a visiting scholar at the Federal Reserve Bank of St. Louis. The author thanks Rosemarie Mueller for research assistance, and Laurence H. Meyer, Joel Prakken and Chris Varvares for providing data and helphul comments. ment begin with the equation:

(1) Investment $=\left[\begin{array}{l}\text { Change in } \\ \text { Desired Capital }\end{array}\right]+$ Depreciation.

Over the long run, the amount of depreciation is determined primarily by the size of the capital stock in place. To explain investment, therefore, one must understand how firms choose their desired stock of capital.'

We begin by analyzing the investment decisions of a representative firm that maximizes its expected earnings over time to increase the wealth of its shareholders. The firm faces constraints on its choices. Some of these constraints, like the firm's technology, are determined by past investment decisions and the longterm development of the economy; other constraints are market-determined, such as interest rates and the availability of funds to finance investment spending. The tax system imposes another constraint on the firm's behavior. To understand its role in investment decisions, we must first see how firms would make investment decisions in the absence of corporate taxation.

\footnotetext{
Equation 1 explains gross investment. Some studies consider the change in desired capital alone, or net investment. The response of investment and the actual capital stock to changes in the desired capital stock will not be immediate; there may be long lags between investment decisions, orders, expenditures and delivery. Estimates of these lags are necessary to predict the timing of investment arising from a change in desired capital. These transitional issues are beyond the scope of this article. The analysis here focuses on the long-run changes in the capital stock caused by the new tax law. For further discussion of short-run adjustments, see Jorgenson's (1971) survey article.
} 


\section{Investment Decisions withont Comporate Tation}

When considering capital expenditure, a firm will compare the revenue that the new investment will produce over its useful life with the costs of purchasing and using the new capital. Because capital goods are durable, they contribute to production over a number of years. It would be incorrect, therefore, to charge the full purchase price of a capital good against revenue in the year it is purchased. Rather, the cost of a capital asset over a year is its opportunity cost; this is simply what the firm gives up by holding it for a year. In the absence of tax effects, the opportunity cost of an investment has two components: interest expense and depreciation. ${ }^{2}$

Suppose a firm uses its own funds to finance an investment expenditure. The firm gives up the opportunity to earn interest on these funds. If the firm borrows from others to finance its investment, then it must pay interest to its creditor. Whether the firm uses its own funds or borrows from others, some measure of interest expense enters the cost of capital.

Actually, only the real interest rate affects the firm's cost of capital. Assume that capital goods prices rise at the same rate as the general price level. If the interest rate were equal to the inflation rate, the firm would not sacrifice any purchasing power by holding capital assets instead of financial assets. Only the portion of interest that exceeds what is necessary to offset expected inflation, real interest, represents a sacrifice for firms that hold capital rather than financial assets. Let $i$ denote the nominal interest rate and $\pi^{e}$ denote the expected inflation rate. Then the real expected interest rate can be closely approximated by $i-\pi^{\circ}$.

These concepts lead to a natural characterization of the way firms determine their desired capital stock and their corresponding investment decisions. New investment increases a firm's output. Economists call this increment to output during a year the marginal product of capital (MPK). The revenue gained from

\footnotetext{
2Rather than analyzing the cost of holding a capital asset year by year, we could compute the present value of the costs over the life of the asset. This would be subiracted from the present value of the revenues generated by the asset to give the net present value. To maximize its shareholder's wealth, the firm would invest in any project with a positive net present value. This procedure is more complicated than the year-by-year analysis presented in the text. It leads to equivalent results, however, assuming that the firm lakes the rate of depreciation and the real rate of interest as constant over the life of the asset.
}

investing in another unit of capital, the value of the marginal product of capital, is $\mathrm{P} \times \mathrm{MPK}$, where $\mathrm{P}$ represents the firm's output price. The opportunity cost of a unit of capital, is its price, $\mathrm{P}_{\varepsilon}$, multiplied by the sum of the real interest rate and the depreciation rate $\left(\mathrm{i}-\pi^{\mathrm{e}}+\mathrm{d}\right.$ ). The insert on the opposite page provides an example calculation of this cost.

If the value of the marginal product of capital, $P \times$ MPK, exceeds the opportunity cost of investment, $P_{c}\left(i-\pi^{e}+d\right)$, the firm can increase its profit by making the investment. On the other hand, if $\mathbf{P} \times$ MPK is less than $P_{v}\left(i-\pi^{e}+d\right)$, the investment is not profitable. To maximize its profits the firm will invest up to the point at which the revenues and costs from additional capital are equal, or,

(2) $\mathbf{P} \times$ MPK $=\mathbf{P}_{c}\left(i-\pi^{\mathrm{H}}+\mathbf{d}\right)$.

The firm's desired capital stock is reached when the last unit of capital purchased satisfies equation 2 . This is a fundamental result in capital theory. It divides the determinants of a firm's desired capital stock into technical (MPK and d) and market factors $\left(\mathbf{P}, \mathbf{P}_{c}\right.$ i). Changes in these factors alter a firm's desired capital stock, and, as equation 1 shows, changes in the desired capital stock along with depreciation determine investment. $^{3}$

\section{TAX REFORM AND THE COST OF CAPITAL}

Of course, equation 2 is strictly valid only in the absence of corporate taxation. But the analysis underlying it helps to explain how the new tax law will affect capital spending. The changes necessary to incorporate corporate taxation into equation 2 are summarized in the insert on page 18 . The key issue considered here is how tax reform has changed the after-tax cost of capital. We shal analyze three changes of particular importance: the repeal of the investment tax credit, the change in depreciation rules and the cut in the corporate tax rate.

\section{Repeal of Investment Tax Credits}

In 1963, the Economic Report of the President stated that "... it is essential to our employment and growth

\footnotetext{
In general, the marginal product of capital in equation 2 will depend on the input of other factors of production along with the capital input. These other factors, labor in particular, are not considered here. For further discussion of this issue, see the Economic Report of the President (1987), pp. 90-93.
} 


\section{Calculating the Cost of Capital: An Example}

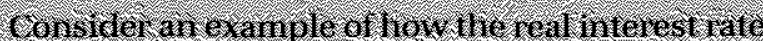

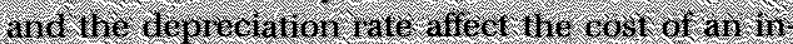

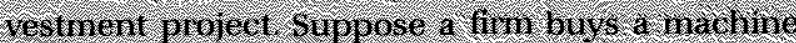

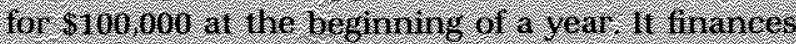

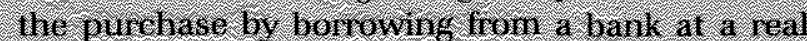

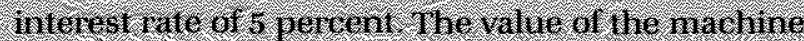

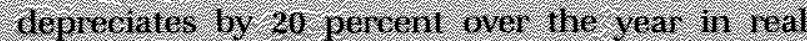
terins, at the and of hie year, 1 o. hin must ho

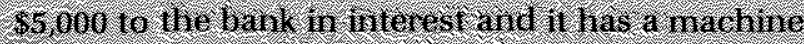

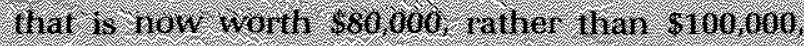

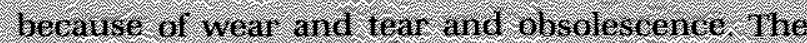

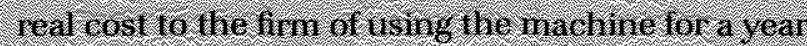

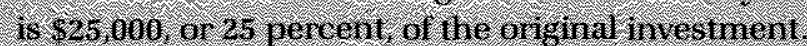

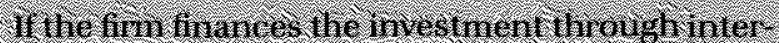

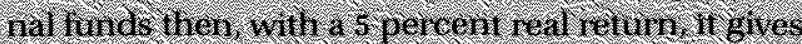

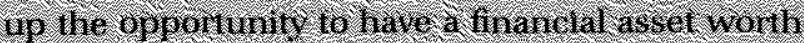

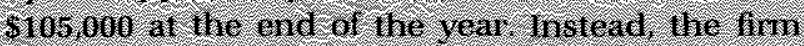

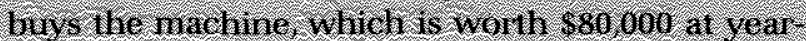
end The rost or cantal is 105000 - $\$ 80000$.

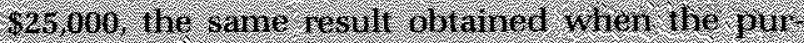

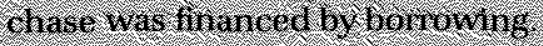

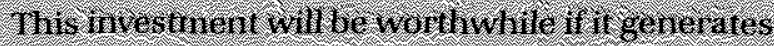

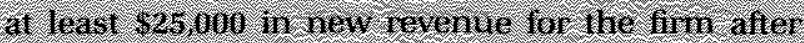

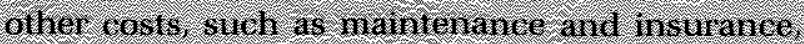
ate arditided objectives as well as to our international competitive stance that we stimulate more rapid expansion and modernization of America's productive facilities." One policy designed to achieve this goal was the investment tax credit, first instituted in 1962. This tax subsidy allowed firms to reduce their taxes by a percentage of their spending on certain kinds of capital equipment.

To integrate this into the capital theory summarized by equation 2 , suppose that the revenues from capital investment are taxed at ate $t$ and the only allowable deduction for capital costs is the investment tax credit at a rate of $k$. Then, the after-tax cost of purchasing a unit of capital is the price paid $\left(\mathrm{P}_{\mathrm{c}}\right)$ minus the investment tax credit amount $\left(\mathrm{k}_{\mathrm{c}}\right)$. The after-tax benefit of investment is $(1-t)$ multiplied by the value of the marginal product of capital. This changes equation 2 to

$$
\text { (3) } \begin{aligned}
P_{s} \times \operatorname{MPK}(1-t) & =\left(P_{c}-k P_{E}\right)\left(i-\pi^{e}+d\right) \\
& =P_{c}(1-k)\left(i-\pi^{e}+d\right) .
\end{aligned}
$$

The investment tax credit reduces the after-tax cost of capital on the right-hand side of equation 3 , increasing the desired capital stock and investment. The new tax bill, by eliminating this subsidy, directly increases a firm's cost of capital, reduces the corporate sector's desired capital stock and depresses investment.

${ }^{4}$ See pages xvi-xvil of the report.

\section{Depreciation Rules: Some Theory}

As capital wears out over time, its value declines, imposing a cost on the firm that should be deducted from its taxable income. A problem arises, however, when this concept is put into practice: how should depreciation costs be determined for tax purposes? From an economic perspective, depreciation is the change in the market value of a capital asset. But market value would be costly for firms to measure and the IRS to verify. As an altemative, the tax code provides schedules prescribing the percentage of an asset's purchase price that can be deducted from each year's taxable income. Changes in these rules lead to changes in the after-tax cost of capital faced by firms.

While all depreciation schedules allow deductions that eventually equal the total historical cost of an asset, the earlier these deductions occur, the more valuable they are. Thus, the after-tax cost of capital is reduced by depreciation schedules that concentrate deductions over a shorter period. Also, "accelerated" depreciation, which permits firms to write off a greater proportion of the asset's cost early in its life reduces the cost of capital relative to "straight line" methods that divide the deductions evenly over the asset's service life." To evaluate the importance of changing

sSee Ott (1984) for a discussion of depreciation methods and an anatysis of the effects of changes in the depreciation rules that occurred in 1981 and 1982 . 


\section{The Effect of Corporate Taxes on the Desired Capital Stock Equation}

In the absence of corporate taxation, firms choose their capital stock to satisfy equation 2 :

$$
\mathbf{P} \times \mathbf{M P K}=\mathbf{P}_{\mathbf{c}}\left(\mathbf{i}-\boldsymbol{\pi}^{0}+\mathbf{d}\right) .
$$

With a proportional tax on corporate income at rate $t$ and an investment tax credit at rate $k$, the equation becomes:

$$
P \times \operatorname{MPK}(1-t)=P_{\varepsilon}(1-k)\left(i-\pi^{8}+d\right) .
$$

Including tax deductions for depreciation allowances with a present value of $\mathrm{z}$ gives:

$$
\mathbf{P} \times \operatorname{MPK}(\mathbf{1}-\mathbf{t})=\mathbf{P}_{\mathrm{c}}(\mathbf{1}-\mathbf{k}-\mathrm{tz})\left(\mathbf{i}-\boldsymbol{\pi}^{\mathrm{t}}+\mathbf{d}\right) .
$$

Finally, recognizing the tax deductibility of nominal

depreciation rules, one must compare the present values of the tax saving over time under the old and new tax laws. An example of how these present values are computed is given in the insert on page 20 .

Consider how the deductibility of depreciation affects the cost of capital. The tax saving will equal the present value of depreciation deductions per dollar of investment $(z)$, multiplied by the corporate income tax rate $(t)$ and the cost of a unit of capital $\left(P_{c}\right)$. Thus, the tax deductibility of depreciation reduces the after-tax cost of a unit of capital by $\mathrm{tzP}_{\mathrm{c}}$. This changes the equation that determines the desired capital stock to

(4) $\mathrm{P} \times \operatorname{MPK}(1-\mathrm{t})=\left(\mathrm{P}_{\mathrm{c}}-\mathrm{kP} \mathrm{P}_{\mathrm{c}}-\mathbf{t z} \mathrm{P}_{\mathrm{c}}\right)\left(\mathrm{i}-\pi^{\mathrm{e}}+\mathrm{d}\right)$

$$
=P_{c}(1-k-t z)\left(i-\pi^{c}+d\right) .
$$

The right-hand side of equation 4 represents the effective cost of capital after accounting for the investment tax credit and depreciation deductions. A reduction in $\mathrm{z}$, the present value of depreciation deductions, increases the cost of capital.

\section{Changes in Depreciation Rules Due to Tax Reform}

The tax acts of 1981 and 1982 instituted the Accelerated Cost Recovery System (ACRS) that increased the tax benefit from depreciation deductions and reduced the cost of capital. The new tax law changes these rules. interest expenses gives:

$$
P \times \operatorname{MPK}(1-t)=P_{c}(1-k-t z)\left(i-\pi^{+}+d-t L i\right),
$$

where $L$ is the firm's marginal proportion of invest ment financed by debt. Rearranging this equation yields:

$$
\left(\mathbf{P} / \mathbf{P}_{\mathrm{e}}\right) \times \mathbf{M P K}=\frac{(\mathbf{1}-\mathbf{k}-\mathbf{t z})}{(1-t)}\left(\mathbf{i}-\pi^{e}+\mathbf{d}-\mathbf{t L i}\right) .
$$

The right side of this equation gives the taxadjusted cost of capital in equation 6 . The calculations in table 2 are based on this formula. See the text for further explanation.

The figures in table 1 compare the present values of depreciation allowances for several representative asset classes over a range of pre-tax interest rates. For equipment purchases, the new tax law changes the present value of depreciation deductions in several ways. First, the service lives for some assets were lengthened. For example, cars and light trucks had their tax service lives extended from three to five years. This reduces the present value of their depreciation allowance, as shown in table 1, because it extends the time between a capital purchase and the tax saving. For many other assets, however, tax service lives were unchanged. Office, computing and accounting equipment, for example, kept its five-year depreciation period. On average, equipment service lives were extended to 6.0 years from their 4.6-year average under ACRS. $^{\circ}$

On the other hand, the new law allows a more accelerated depreciation schedule (firms may use a 200 percent, rather than a 150 percent, declining balance depreciation method). This allows a greater proportion of the total deduction in the earlier years. By itself, this change would increase the present value of

'The average service life estimates used in this article are weighted averages over the different classes of assets. The weights reflect the proportion of total assets in each class. The author thanks Joel Prakken of Laurence $\mathrm{H}$. Meyer and Associates for providing these estimates. 


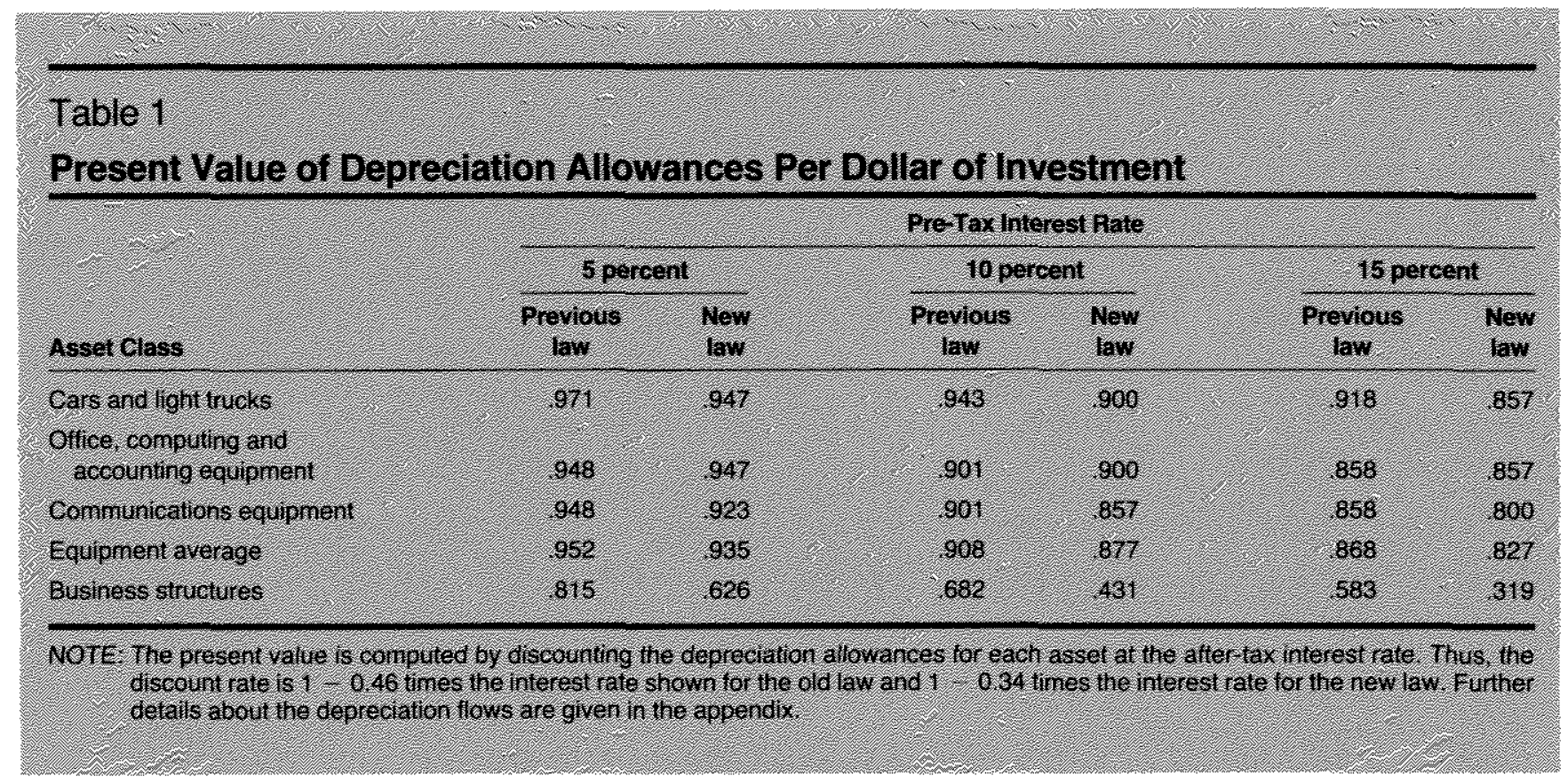

depreciation deductions, thus partly offsetting the negative impact of extending service lives.

Finally, by reducing the corporate tax rate, the new tax law increases the after-tax discount rate firms use to calculate the present value of their depreciation deductions at a given nominal interest rate. By itself, this reduces the present value of a particular sequence of depreciation deductions.

As table 1 shows, on net these changes cause the present value of depreciation allowances to decline under the new tax law. The effects for equipment are modest on average.

The new law has a much more significant impact on business structures. The ACRS system adopted in 1981 allowed firms to depreciate business structures over 19 years with an accelerated method (175 percent declining balance). The new law requires straight line depreciation over 31.5 years. As the bottom row of table 1 shows, this significantly reduces the present value of depreciation allowances for structures.

\section{Changes in the Corporate Tax Rate}

The new tax law cuts the top corporate income tax rate from 46 percent to 34 percent. By itself, it might seem that this would stimulate investment, because it allows firms to keep a larger proportion of the profits eamed from new capital. The analysis that led to equations 2 through 4 shows that this may not be the case. Although a cut in the corporate income tax rate increases the after-tax revenues gained from new in- vestment, it also decreases the value of tax deductions generated by capital costs. Thus, the net effect on investment of a lower corporate tax rate is ambiguous. It depends on the extent to which capital costs are taxdeductible.

Let us consider this point in more detail. The cost of capital per dollar of investment is reduced by the corporate tax rate times the present value of depreciation allowances $(t z)$. The lower the corporate tax rate, the lower the value of this deduction, and the higher the after-tax cost of capital. Thus, considering this channel alone, lowering the corporate tax rate actually reduces the incentive to invest.

Anothes primary component of capital cost is real interest earnings foregone by investing in fixed capital. In the absence of corporate taxation, this cost was essentially the same whether firms financed their investment with intemal funds or external borrowing. This is no longer true when we introduce the corporate income tax. Nominal interest paid on debt is taxdeductible, but foregone interest on internal funds is not. This gives debt financing a tax advantage over internal financing. "The tax saving from interest deductions is the corporate tax rate (1), multiplied by the proportion of the investment financed with debt (L), multiplied by the nominal interest rate $(i)$. This amount is subtracted from the real interest rate in the

7See Brealey and Myers (1984) for a clear summary of this idea. 


\section{The Present Value of Depreciation Deduetions}

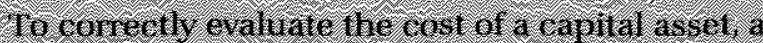

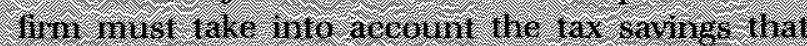

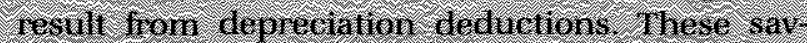

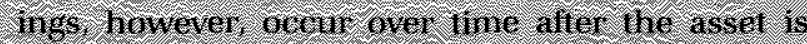

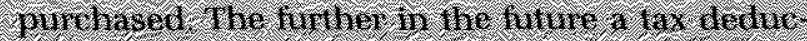

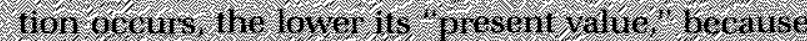

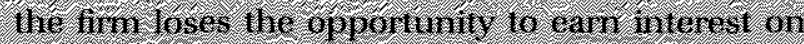

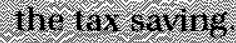

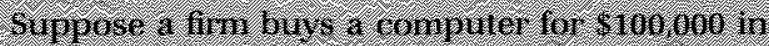

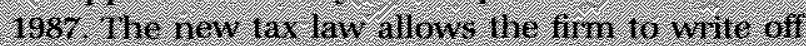

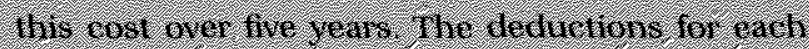

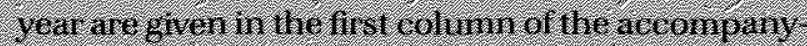

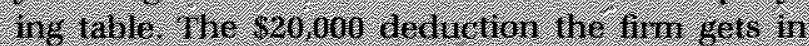

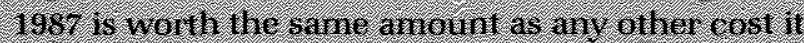

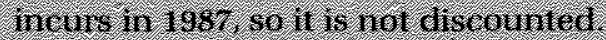

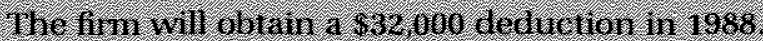

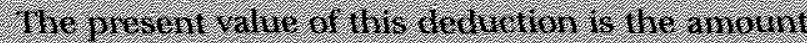

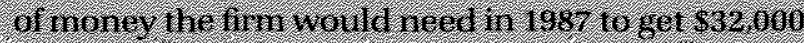
in 1988. tssuine IIe pretax mimest rate is 10 per

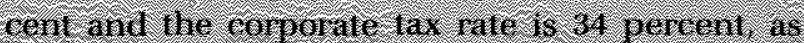

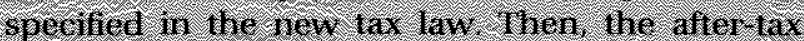

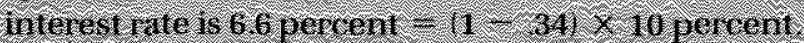

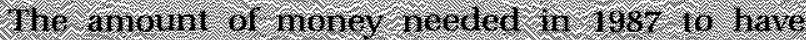

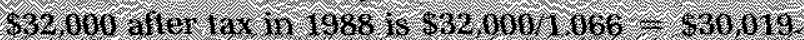

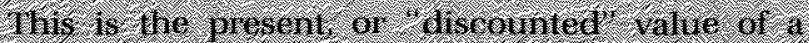

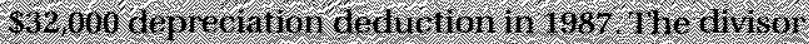

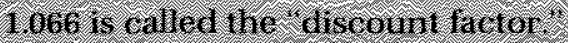

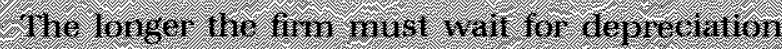

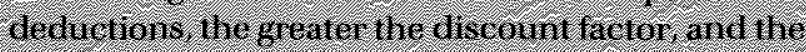

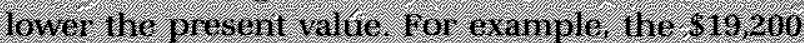

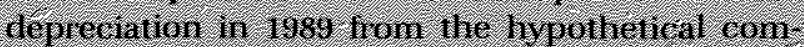

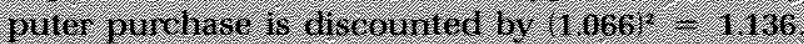

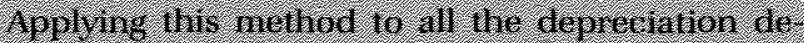

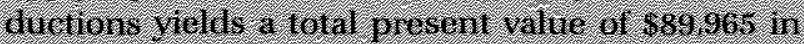

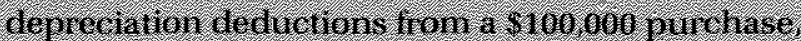

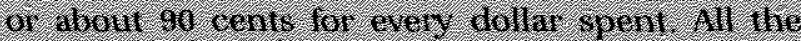

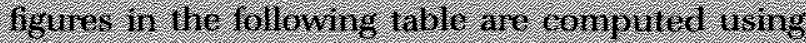
1his upharth

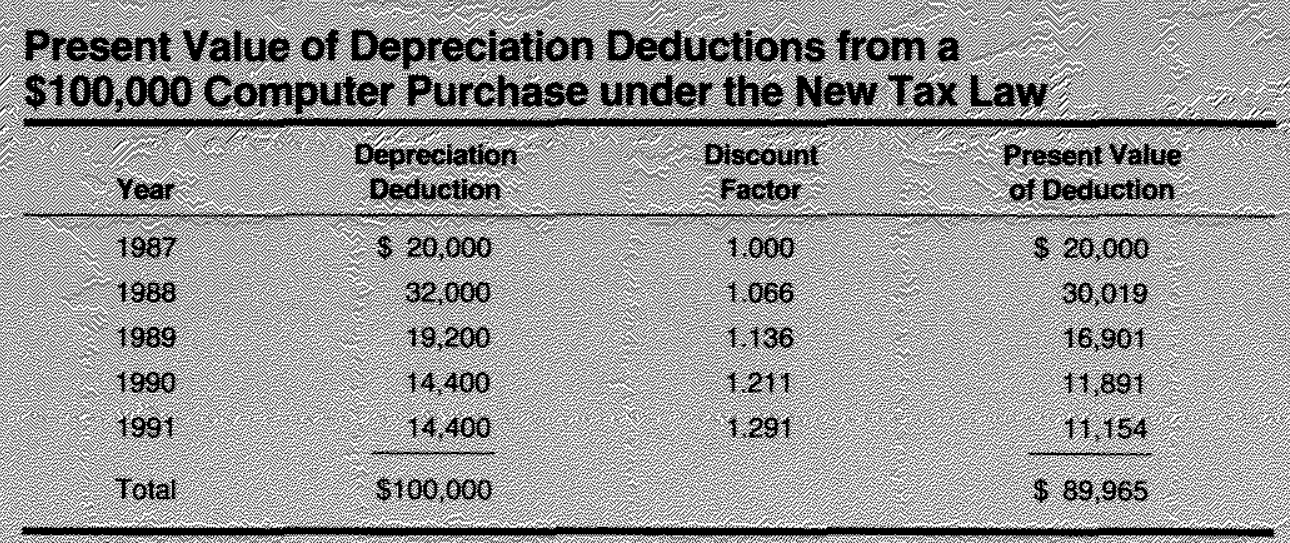

capital cost in equation 4 , which now becomes:

(5) $\mathrm{P} \times \operatorname{MPK}(1-t)=P_{\mathrm{s}}(1-\mathrm{k}-\mathrm{t} z)\left(\mathrm{i}-\pi^{\mathrm{e}}+\mathrm{d}-\mathrm{tLi}\right)$.

As noted previously, the corporate income tax rate also affects the revenue side of the investment decision. The effective value of the marginal product is (1-t) $\mathbf{P} \times$ MPK. A lower corporate tax rate stimulates investment through this channel; with lower taxes, firms keep a larger proportion of the revenues generated by new investment.
In summary, reducing the corporate tax rate increases the benefits from new capital investment by rassing the left side of equation 5 . At the same time, lower corporate tax rates reduce the value of tax deductions for depreciation and interest expense. This increases the costs of new capital on the right side of equation 5. Therefore, this theory cannot predict whether the lower corporate tax rate will stimulate of depress investment. To obtain a more definite result, we must look at the net effects of changes in the tax law. 
Table 2

\section{The Effects of Tax Reform on the After-Tax Cost of Capital}

\begin{tabular}{|c|c|c|c|c|c|}
\hline $\begin{array}{l}\text { Inrestiment } \\
\text { Category }\end{array}$ & 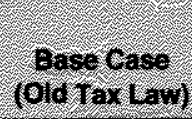 & 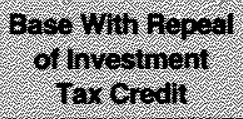 & 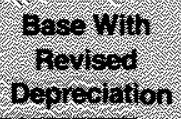 & 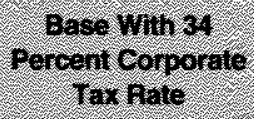 & 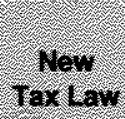 \\
\hline Cars and 19 hr rueks & 36010 & $39,4 \%$ & 3756 & $362 \%$ & $399 \%$ \\
\hline $\begin{array}{l}\text { Offer, computing and } \\
\text { accounting equiphel }\end{array}$ & 296 & 843 & 296 & 29.5 & 356 \\
\hline 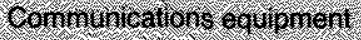 & 156 & 18.0 & 161 & 15.7 & 182 \\
\hline Eguiprientaverage & 17,1 & 10.6 & 17.5 & 172 & 19.6 \\
\hline Business siugtures & 102 & 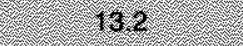 & 15.4 & 125 & 169 \\
\hline
\end{tabular}

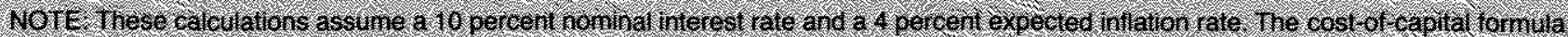
and additonar assumptons are given in the appendix.

\section{Net Effects of Tax Changes on the Cost of Capital}

To fully assess the impact of tax reform on the cost of capital, we need a way of combining all the changes into a single measure. The basis for this is the theory summarized in equation 5. By putting all the terms affected by the tax system on the right side of the equation, we obtain:

(6) $\left(\mathbf{P} / \mathbf{P}_{\mathrm{k}}\right) \times \mathrm{MPK}=\frac{(\mathbf{1}-\mathbf{k}-\mathbf{t z})}{(1-\mathbf{t})}\left(\mathbf{i}-\pi^{e}+\mathrm{d}-\mathbf{t L i}\right)$.

The right side of this equation is the tax-adjusted cost of capital per dollar of investment spending. Some representative calculations of this cost are shown in table $2{ }^{8}$ The differences among the cost of capital estimates for different asset classes are primarily due to different rates of economic depreciation.

The first column of table 2 gives cost of capital estimates based on assumptions that reflect the old

"The basic reference for the tax-adjusted cost of capital measure is Hall and Jorgenson (1967). Further details of the calculation are given in the appendix. To make the comparisons shown in table 2, one must make assumpiions about the future course of nominal interest rates and expected inflation. The calculations in table 2 assume a nominal interest rate of 10 percent and expected inflation of 4 percent. These assumptions are the same for the old and new tax laws to focus on the results of tax changes alone. Some economists have argued that the tax reform will change interest rates and inflation. This issue is considered later in the article. Also, these calculations do not consider the effects of changes in personal taxes on capital income. See Henderson (1986) for further discussion of this issue. tax law. The second column shows the effect of eliminating the investment tax credit, while retaining all other assumptions of the base case. This has a significant impact on the after-tax cost of capital for equipment. The average equipment cost of capital rises by 2.4 percentage points with the repeal of the investment tax credit. The credit does not apply to structures. ${ }^{9}$

On the other hand, the third column shows that the effect of changing the depreciation rules is more pronounced for the after-tax cost of business structures. The present value of depreciation deductions declines much more for structures than for equipment under the new tax law. Compared with the base case of the old tax law, the change in tax depreciation rules raises the after-tax cost of capital by only 0.4 percentage points for equipment, on the average, while raising the cost of capital by 2.2 percentage points for business structures.

The fourth column shows the effect of lowering the corporate tax rate from 46 percent to 34 percent. This causes a substantial reduction in the cost of capital for business structures, but leaves the equipment figures virtually unchanged. The analysis in the previous section explains this result. Theoretically, the net effect of

\footnotetext{
9in econometric analysis that uses National income and Product Accounts (NIPA) data, the investment tax credit for structures is often not set at zero. This is because the NIPA data for structures include asset classes, drilling rigs and air-conditioning equipment, for example, which were eligibie for the credit. This is not important, however, for the illustrative calculations in table 2
} 
a lower corporate tax rate on the cost of capital is ambiguous. The direction of change depends on the value of tax deductions for depreciation. The depreciation deductions for equipment per dollar of investment are much more valuable than those for business structures, because equipment write-offs are faster. Thus, lowering the corporate tax rate reduces the value of equipment depreciation allowances more than business structures allowances. On the other hand, the benefit of lower corporate taxes - from the reduced proportion of revenues paid in taxes - is the same for both equipment and structures. Thus, lower corporate tax rates benefit structures much more than equipment, as the fourth column of table 2 shows.

The aspects of the tax reform bill that affect the cost of capital have drawn significant criticism because some analysts view them as anti-growth. The results presented in table 2 provide some support for this view. The last column shows the net effect of the new tax law. All the cost of capital estimates rise relative to the old law. For equipment, the repeal of the investment tax credit has the most important effect, and some asset classes face higher costs due to changes in the depreciation rules.

For business structures, the change in depreciation has a significant impact by itself, but this is offset to a large degree by the benefits of a lower corporate tax fate. The comparatively moderate increase in the cost of capital for business structures is somewhat surprising in light of the strong criticism the new tax treatment of structures has drawn. This is probably because most analyses focus on the more obvious effect of less generous structure depreciation. But it is important not to ignore the important impact of lower corporate tax rates. ${ }^{\text {to }}$

\section{THE IMPACT OF TAX REFORM ON INVESTMENT AND THE CAPITAL STOCK}

How large an effect will changes in the cost of capital have on U.S. investment and the capital stock? This is not an easy question to answer. Economists have not resolved important technical questions about the sensitivity of the desired capital stock to changes in the after-tax cost of capital. Furthermore, many economists have argued that tax reform will lower the real interest rate. The calculations presented in table 2 assume that real interest rates do not change under the new tax law.

\section{The Link between Investment and the Cost of Capital}

Economists generally agree that the new tax law will increase the cost of capital. The effect of this increase on investment and the desired capital stock depends on the economy's production technology. The key parameter is called the "elasticity of substitution" between capital and other factors of production. This measures the sensitivity of firms' demand for capital to changes in the cost of capital. An increase in the cost of capital induces firms to substitute other factors of production for capital. This lowers the desired capital stock, and according to equation 1 , investment falls. The higher the elasticity of substitution, the bigger the reduction in the long-run capital stock.

Let $c_{0}$ and $c_{n}$ represent the cost of capital under the old and new tax laws, respectively. The theory predicts that the long-run percentage change in the capital stock is given by:

(7) Percent Change in Capital $=100 \times\left[\left(c_{w} / c_{n}\right)^{s}-1\right\}$,

where $s$ is the elasticity of substitution. The assumptions used to derive equation 7 are discussed in the appendix. The higher $s$ is, the greater the long-run reduction in the capital stock will be as a result of tax reform.

The elasticity of substitution is determined by the economy's technology. Although not directly observable, it can be estimated, and a wide range of estimates of $s$ can be found in the economics literature. Some researchers have concluded that the elasticity of substitution is close to unity. ${ }^{11}$ If this is true, the size of the desired capital stock would be very sensitive to changes in the cost of capital. Thus, even the modest increase in the cost of capital shown in table 2 could have a significant long-run impact on the capital stock.
${ }^{10}$ Of course, this point is relevant only for profitable firms that invest in structures. Firms that invest only to obtain tax losses from fat depreciation allowances will be hurt by the new depreciation rules, but, since they pay no tax, will not be helped by lower tax rates.

\footnotetext{
It If the elasticity of substitution is equal to one, the economy's technology can be represented by a Cobb-Douglas production function. Jorgenson (1971) finds empirical support for this case. Also see Chirinko and Eisner (1982) for further discussion.
} 
With s equal to 1.0 in equation 7 and the cost of capital figures from table 2 we obtain the following results:

$$
\begin{aligned}
& \text { Percent Change } \\
& \begin{aligned}
\text { in Equipment } & =100 \times((17.1 \% / 19.6 \%)-1] \\
& =-12.8 \%
\end{aligned}
\end{aligned}
$$

Percent Change

in Structures $=100 \times[(13.2 \% / 13.9 \%)-1]$

$$
=-5.0 \%
$$

These dramatic results support the views of tax reform critics. A 12.8 percent drop in the stock of U.S. capital equipment would cause a significant reduction in the economy's productive potential with a correspondingly negative impact on future national output and employment. ${ }^{12}$

Other researchers have found that the desired capital stock is much less sensitive to changes in the cost of capital. For example, in an extensive survey of predictions from lange econometric models, Chirinko and Eisner (1982) found estimates of $s$ as low as 0.55 for equipment and 0.16 for structures. Such low values change the predicted effects of tax reform significantly:

$$
\begin{aligned}
& \text { Percent Change } \\
& \begin{aligned}
\text { in Equipment } & =100 \times\left[(17.1 \% / 19.6 \%]^{0.5 \%}-1\right] \\
& =-7.2 \%
\end{aligned}
\end{aligned}
$$

Percent Change

in Structures $=100 \times\left[(13.2 \% / 13.9 \%)^{\% .16}-1\right]$

$$
=-0.8 \% \text {. }
$$

These results suggest that tax reform could have a more moderate effect on equipment and virtually no effect on structures.

\section{Tax Reform, Interest Rates and Investment}

The analysis up to this point has assumed that the interest rate would not be affected by tax reform. Yet, there are widespread predictions that tax reform will

\footnotetext{
2 Some economists have argued that, although investment and the capital stock will fall as a result of tax reform, the projects that are underiaken will be more efficient. Eliminating special tax breaks for certain kinds of investment wi非 encourage firms to carry out more productive projects rather than projects that generate the biggest tax savings. Thus, the fall in investment may benefit the economy by reducing wasteful investment. A complete analysis of this issue is outside the scope of this article. See Batten and Ott (1985), Henderson (1986), and the Economic Report of the President (1987), pp. $86-93$, for further discussion.
}

decrease interest rates. The tax reform bill cuts marginal personal tax rates sharply, especially for highincome individuals. Thus, the after-tax returns to saving rise, which stimulates saving and lower real interest rates. Furthermore, reduced capital spending lowers the demand for financing. This also pushes real interest rates lower. One recent study, for example, predicts that the new tax law will cause a 1.3 percentage-point decline in the corporate bond yield and a 0.5 percentage-point decline in the inflation rate. Under these circumstances, the real interest rate would decrease 0.8 percentage points. ${ }^{33}$

The effects of lower interest rates are explored in table 3. The first column reproduces results given earlier for the percentage changes in the capital stock assuming no changes in real interest rates due to the new tax law. Figures are given for both the high elastic ity of substitution case ( $\mathrm{s}=1)$ and the low elasticity case $i s=0.55$ for equipment and $s=0.16$ for structures). The columns show the effects of a range of assumptions about the decline in the interest rate induced by tax reform.

These figures show that even modest reductions in real interest rates from the new tax law can substantially mitigate the negative impact of tax reform on investment. The effects on the stock of producers' durable equipment are moderate, especially with the lower elasticity of substitution estimate. Surprisingly, the calculations show that the desired stock of business structures may even rise with real interest rate reductions in the middle of the relevant range. Thus, the dramatic reductions in the capital stock and investment predicted by some critics of the new tax law represent a worst case, whene the elasticity of substitution is high and the real rate of interest does not fall in response to tax changes.

\section{The Effects of Increasing Corporate Tax Burdens}

The analysis to this point has used conventional capital theoretic concepts to evaluate the impact of tax reform on investment incentives. Tax policy affects investment decisions by changing the costs and benefits of individual investment projects. A firm can obtain financing for any profitable project at the prevailing cost of capital. Thus, the reduction of a fimn's intemal funds available to finance investment caused

\footnotetext{
13These estimates are from Prakken (1986), p. 30. Some economists have argued that the fall in long-term interest rates during 1986 was due, at least in part, to expectations that the new tax law would reduce interest rates.
} 


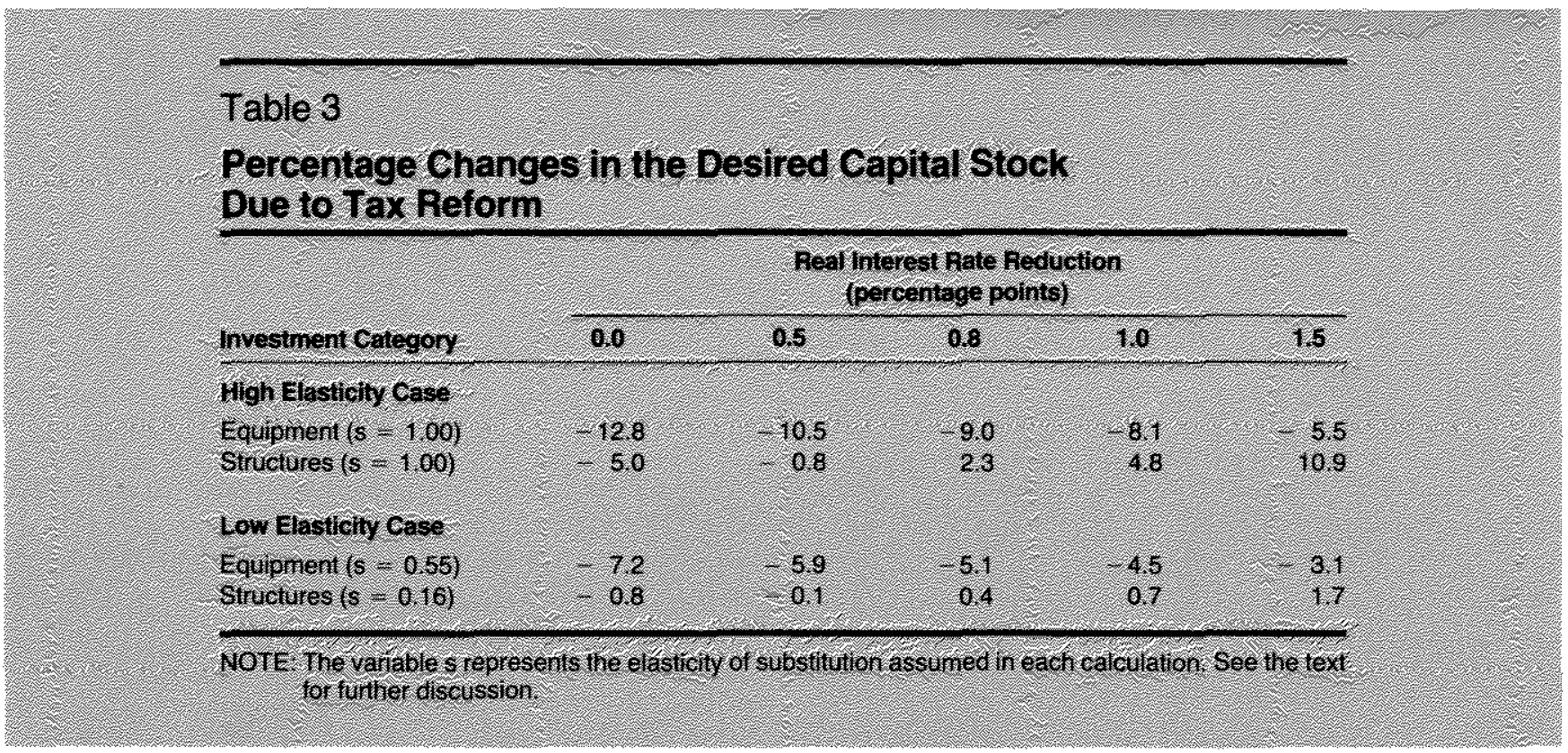

by the new tax law does not directly affect investment. Firms offset the decline in internal cash flow by borrowing the necessary funds in external capital markets. ${ }^{\text {t4 }}$ The economics literature, however, has identified reasons why this view may not be valid.

The assumption that all desired investment can be financed at the market interest rate ignores the problem of communicating information from borrower to lender. It is costly for lenders to evaluate the prospective returns of various investment projects because they do not have extensive knowledge of the particular situations facing potential borrowers. While borrow. ers will provide some relevant information, they have an incentive to present an optimistic view of their circumstances. Thus, lenders may be willing to finance some investment projects only at interest rates so high that these projects become unprofitable. Furthermore, as various studies have shown, when capital market information is costly, some firms may not be able to obtain external financing even at high interest rates ${ }^{15}$ In this case, the new tax law could

\footnotetext{
${ }^{14} \mathrm{An}$ immediate objection that might be raised against this view is that firms must pay interest on external funds, so borrowing appears more costly than internal finance. This is true on the firm's income statement. But in economic terms, the firm also gives up the opportunity to earn interest on internal funds when they are spent on capital accumulation.

15This situation is called "credit rationing" in the economics literature. Stiglitz and Weiss (1981) present a theoretical model that explains this possibility. This idea is linked to investment theoretically by Greenwald, Stiglitz, and Weiss (1984) and empirically by Fazzari and Athey (1987).
}

reduce investment because firms would not be able to offset the loss of internal funds by borrowing.

Furthermore, even if lenders are willing to provide funds at favorable market interest rates, firms themselves may be reluctant to use credit markets to recover investment finance lost under the new tax law. Firms are concerned about their debt-equity ratios and their credit ratings. Thus, they may choose to curtail capital expenditures rather than increase borrowing. New equity issues are a potential source of funds, but the historical evidence shows that little new investment is financed through new share issue. ${ }^{16}$

How big an impact will tax reform have on investment through this channel? The investment equation 1 can be modified to address this question:

(8) Investment $=$ Depreciation $+\left(\begin{array}{c}\text { Change in } \\ \text { Desired } \\ \text { Capital }\end{array}\right)+\left(b \times \begin{array}{c}\text { Cash } \\ \text { Flow }\end{array}\right)$.

The parameter b represents the size of the effect of internal cash flow on investment. Estimation of $b$ from

\footnotetext{
EIn a detailed study of 12 large companies over 10 years, Donaldson and Lorsch (1983), p. 52, show that only 0.5 percent of new funds raised resulted from equity issues. They also find a strong preference for internal investment firancing, rather than debt financing. Common and preferred stock issues accounted for only 3.9 percent of the sources of funds for 799 industrial firms reported on the Vaue Line database in 1984. Greenwald, Stiglitz and Weiss (1984) provide a theoretical explanation, based on capital market signaling, for why firms avoid equity finance.
} 
historical data shows that cash flow has been positively related to equipment investment over the last three decades; cash flow had no significant effect, however, on business structures investment. The details of the estimation are presented in the appendix.

These estimates provide one way to predict the effect of increasing corporate taxes while reducing personal taxes. Suppose, in the absence of tax changes, that real equipment investment would grow from mid-1986 through 1988 at a 5 percent annual rate. Now suppose that the new tax act will increase corporate taxes by $\$ 25.2$ billion in 1987 and $\$ 23.9$ billion in 1988 . $^{\text {t }}$ Then, the estimates of equation 8 predict a 2.8 percentage-point reduction in equipment investment for 1987 and a 2.1 percentage-point reduction in 1988 , relative to the benchmark 5 percent real growth trend. While not especially large relative to historical variations in equipment investment, these changes are still substantial. ${ }^{\text {s }}$

There is an important qualification to these predictions. The calculations are based on the assumption that firms absorb the whole tax increase in reduced cash flow rather than increasing before-tax markups to recover part of the tax increase through higher prices. This assumption becomes less realistic as the forecast horizon expands further into the future and firms revise their pricing policies to reflect the new tax system. This eventually could reduce or even eliminate the effect of higher taxes on corporate cash flow.

\section{CONCLUDNG REMARKS}

How big an impact will tax reform have on investment? The analysis presented here shows a rather wide range of possibilities. Capital theory implies that the new tax law will increase the cost of capital, especially for producers' durable equipment investment, tending to reduce investment and lower the U.S. capital stock. The size of this effect, however, is uncertain. Under some assumptions, the rising cost of capital leads to a dramatic 13 pencent long-run fall in the

\footnotetext{
The 5 percent arnual growh rate was the actual growth rate of real producers' durable equipment invesiment from the second quarter of 1985 througth the second quarter of 1986 . It gives a benchmark tor equipment investment growth in the absence of tax reform. The estimated changes in corporate taxes were obtained from the con. gressional conference committee repot on the Tax Reform Act of 1986. See Bureau of National Affair's, Inc. (1986).

1 The standard deviation of the producers' real durable equipment growth rate from 1970 through 1985 was 9.9 percentage points.
}

stock of equipment. Different assumptions, however, lead to much smaller changes. Moreover, lower interest rates caused by tax changes will likely offset some of the rise in after-tax capital costs due to changes in tax rules.

The 1987 Economic Report of the President predicts that "a somewhat higher overall marginal tax rate on capital income will modestly reduce the economy's long-run capital intensity" (p. 79). The analysis presented in this article supports this view. A middle-ofthe-road forecast indicates that the new tax law alone will cause a moderate decline in equipment investment, chiefly due to the repeal of the investment tax credit. The effects on business structure investment will likely be small, at least for structure investment motivated by economic profits as opposed to tax benefits (see footnote 10). The rollback of generous depreciation treatment for structures increases their after-tax cost, but the lower corporate tax rate and the potential for lower real interest rates largely offset the depreciation rule change.

\section{REFERENCES}

Batten, Dallas S., and Mack Ott. "The President's Proposed Corporate Tax Retoms: A Move Toward Tax Neutrality," this Review (August/September 1985), pp. 5-17.

Brealey, Richard, and Stewart Myers. Principles of Corporate $\mathrm{F}$ nance (McGraw Hill, 1984).

Bureau of National Affairs, Inc. "Conterence Report (H Rept. 99841 ) on HR 3838, 'Tax Reform Act of 1986," DER No. 183 (September 22, 1986).

Chirinko, Robert, and Robert Eisner. "The Effects of Tax Parameters in the Investment Equations in Macroeconomic Econometric Models" in Marshall Blume, Jean Crockett, and Paul Taubman, eds., Economic Activity and Finance (Ballinger Publishing Company, 1982).

Clark, Peter. "Investment in the 1970s: Theory, Pertormance, and Prediction, "Brookings Papers on Economic Activity (1979) pp. 73 124.

Donaldson, Gordon, and Jay W. Lorsch. Decision Making at the Top (Basic Books, inc., 1983).

Economic Report of the President. (U.S. Government Printing Office, 1963 and 1987 ).

Fazzari, Steven, and Michael Athey. "Asymmetric Information, Financing Constrairts, and Investment," Review of Economics and Statistics (forthcoming, 1987).

Greenwald, Bruce, Joseph Stiglitz, and Andrew Weiss. "Informational Imperfections in Capital Markets and Macroeconomic Fluctuations," American Economic Review (May 1984), pp. 194-99.

Hall, Robert, and Dale Jorgenson. "Tax Policy and investment Behavior," American Economic Review (June 1967), pp. 391-414.

Henderson, Yolanda. "Lessons from Federal Reform of Business Taxes," New England Economic Review (November/December 1986), pp. 9-25. 
Jorgenson, Dale. "Econometric Studies of Investment Behavior: A Survey," Journal of Economic Literature (1971), pp. 111:-147.

Ott, Mack. "Depreciation, Inflation and Investment Incentives: The Effects of the Tax Acts of 1981 and 1982," this Review (November 1984), pp. $17-30$.
Prakken, Joel. "The Macroeconomics of Tax Reform," presented at the American Council for Capital Formation conference entitled "The Consumption Tax: A Better Alternative?" (September 1986).

Stiglitz, Joseph, and Andrew Weiss. "Credit Rationing in Markets with Imperfect Information," American Economic Review (June 1981), pp. 393-410.

\section{Technical Appendix}

\section{A. Present Value of Depreciation Allowances}

The tax service life for cars and light trucks under the old tax law was three years. It has been lengthened to five years under the tax reform act. The tax service lives for office, computing and accounting equipment, and communications equipment were five years under the old law. Tax reform did not change the depreciation period for office, computing and accounting equipment, but it extended the service life for comw munications equipment to seven years. The tax service lives are based on the Asset Depreciation Range system. See Ott (1984) for further details.

Depreciation allowances for equipment were computed using a 150 percent declining balance method under the old tax law and a 200 percent declining balance under the new law. A switch to straight-line depreciation to maximize the deduction is also assumed. These methods are discussed in detail in Ott (1984). The half-year convention was used that treats all purchases within a year as if they occur at midyear.

To compute the present value, depreciation deductions were discounted at an after-tax rate obtained by multiplying the nominal interest rate by one minus the appropriate marginal corporate tax rate.

\section{B. Cost of Capital}

The cost of capital calculations in the text are based on the Hall and Jorgenson (1967) formula. The cost of capital, often called the implicit capital rental rate, is given by the formula:

$c=100 \times \frac{1-k-t z(1-0.5 \times k)}{1-t}[(1-t L) i-\pi+d]$ where

$\mathrm{k}=$ imvestment tax credit rate,

$t=$ corporate tax rate,

$\mathbf{z}=$ present value of a one dollar depreciation allowance,

$L=$ leverage ratio (debt as a proportion of assets),

$i$ = nominal interest rate,

$\mathrm{d}=$ economic depreciation rate, and

$\pi^{e}=$ expected inflation rate.

A leverage ratio of 0.306 , based on data from the Washington University Macro Model (WUMM), was used in all the calculations.

The capital stock calculations given in the text are based on a constant elasticity of substitution aggregate production function. With this technology, the desired capital stock is proportional to $\mathrm{c}^{-s}$ where $\mathrm{c}$ is the cost of capital defined above and $s$ is the elasticity of substitution. These calculations assume that the level of output and the ratio of the price of investment goods to the price of output are constant.

\section{Estimated Eifect of Cash Flow Changes on Investment}

The estimated reductions in equipment investment due to lower corporate cash flow caused by tax reform are based on the regression equation:

$$
\begin{aligned}
& \mathrm{INVE}_{\mathrm{z}}=\underset{(0.0153)}{0.0994 \mathrm{~K}_{\mathrm{t}-\mathrm{s}}}+0.0174 \mathrm{f}\left(\frac{\mathrm{P}_{\mathrm{t}} \mathrm{Y}_{\mathrm{t}}}{\mathrm{E}_{\mathrm{t}} \mathrm{C}_{\mathrm{t}}}-\frac{\mathrm{P}_{\mathrm{t}-\mathrm{t}} \mathrm{Y}_{\mathrm{t}-1}}{\mathrm{E}_{\mathrm{t}-\mathrm{t}} \mathrm{C}_{\mathrm{t}-1}}\right) \\
& +0.2081 \mathrm{IFIN}_{t}+0.0953 \mathrm{IFIN}_{t-1}+0.0136 \mathrm{IFIN}_{t-2} \text {, } \\
& (0.0380) \quad(0.0538) \quad(0.0534)
\end{aligned}
$$

where

$$
\begin{aligned}
\text { INVE, }_{\mathrm{s}} \text { - } & \text { producers' durable equipment investment at time } \\
& t \text { in } 1982 \text { dollars, } \\
K_{1-x}= & \text { lagged stock of equipment (as calculated for } \\
& \text { WUMM), }
\end{aligned}
$$


$P_{1}=$ implicit price deflator for private non-farm output,

$\mathbf{E}_{1}$;.mimplicit price deflator for producers' durable equipment,

$Y_{\mathrm{r}}=$ real private, non farm output $t_{+}$and

IFIN $_{r}$ : internal finance, defined as after-tax corporate profits plus depreciation allowances minus corporate dividends, deflated by $\mathrm{E}_{\mathrm{t}}$.
Standard errors of the estimated coefficients appear beneath the estimates. The f( $\bullet$ function represents a 14-quarter, third-degree polynomial distributed lag. The equation was estimated with a correction for first order autocorrelation of the residuals, with quarterly data from the third quarter of 1956 through the second quarter of 1986. 